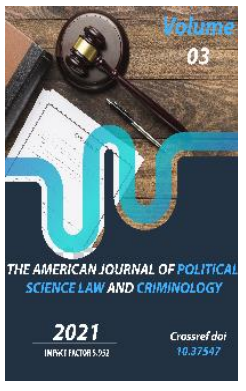

Journal Website: https://theamericanjou rnals.com/index.php/ta jpslc

Copyright: Original content from this work may be used under the terms of the creative commons attributes 4.0 licence.

\section{Priorities Of Providing The Economic Basis Of Sovereignty}

\author{
Shavkat Gaybullaevich Asadov \\ DSc (Law), Professor Of Department Of "Department Legal Basis Of Public Administration And \\ Structure" Of The Academy Of Public Administration Under The President Of The Republic Of \\ Uzbekistan
}

\title{
ABSTRACT
}

The economic sovereignty of the state means that the people are free to manage their national wealth, to freely determine the ways of using their natural resources for the purposes of economic and social development. At the same time, "the economic sovereignty of the state is a set of formalized rights to make decisions independently within the powers in the economic sphere" $[1,16]$. It means exercising absolute control over its natural resources and taking internal control of the activities of any enterprise in all sectors of the economy. Uzbek economist M.N. Yusupova [2, 7-9] argues that the basis of economic sovereignty is not material resources and wealth, but labor resources, which is an important factor in the national awakening.

\section{KEYWORDS}

Uzbek economist, system of society, globalization, demographic inequality, Central Asian countries.

\section{INTRODUCTION}

The main force driving global change is the economic system of society. There are processes associated with the globalization of production and capital, the growth of international trade, the transfer of productive forces from developed to developing countries and the reverse movement of labor. Modern society is moving along the dynamics of the objective laws of market relations and is becoming a locomotive of globalization processes.According to I.D. Levin, property is the basis for the full power of any social stratum in society. The primary interests of any state are its economic interests [3, 27], the weakening of economic potential (e.g., deindustrialization, the crisis of agriculture, the 
disruption of the energy system and etc.) undermines the basis of state sovereignty. Creating a legal framework for economic integration with Central Asian countries. Today's process of globalization shows that the integration of the whole world, including Central Asia, must be manifested in a new form. Sustainable development, opening of diversified access to world markets, modernization of the national economy are especially important for Central Asian countries.

According to M.Porter, "at the moment it is impossible to imagine the development of any state in the world in isolation from the international community, and the life of the country does not depend only on the domestic policy of the state" $[4,128]$. According to F.Tolipov, "the interests of many world and regional powers intersect in Central Asia, which will help prevent any of them from absolute domination in the region. Accordingly, Central Asia can play an active role in the global geopolitical reconstruction process that is most likely to take place in the 21st century" [5, 194]. Now, without integration, without supremacy, regardless of its form, the Central Asian states will have neither economic, cultural nor social development, but the region can become a continuation of it after the withdrawal of NATO troops from Afghanistan.

The first President of the Republic of Kazakhstan, Nursultan Nazarbayev, was one of the first to take such initiatives and put forward the initiative to create a union of Central Asian states [6].

Are Central Asian countries ready for integration today? What values should be primary as a key factor in the integration of states? In our view, the Central Asian countries, which for a quarter of a century have begun to build the mechanisms of a market economy independently and have more or less experienced human resources, are ready for integration, at least economic integration. There is no denying that some factors have a positive and some negative effects on the integration of states. We can positively assess the fact that the majority of the peoples of the countries believe in Islam, the closeness of language and mental values, and historically, economic and social development have always been under a single system, and the ties of cooperation have survived. Also, Russia, China and the United States have conflicting geopolitical interests in the Central Asian region, the alienation of societies as a way of social life as a result of the republics' efforts to build national statehood after the crisis of the former Soviet regime, the ongoing civil war in Afghanistan, differences in the distribution of natural resources, demographic inequality, the basis of the economy and the diversity of economic development paths have a negative impact on integration.

According to M.Suyunbaev, the prospects for economic development in the Central Asian region now require integration. First, in Soviet times, integration did not actually exist (this integration was with Moscow, not between the republics); secondly, the transfer of some powers in presidential republics to integrated structures will be more difficult than in parliamentary republics. Finally, the formation of statehood in the countries of the region almost coincided with the acceleration of globalization processes and led to the sovereignty (identification) of countries. Eventually, this led to the destruction of identity and was the main reason for the 
disintegration of the existing integration system in the region [7, 57].

To what extent does the integration of Central Asian states affect the preservation of their national statehood, including Uzbekistan, and the provision of state sovereignty and independence? For example, Article 17 of the Constitution of the Republic of Uzbekistan, the concept of foreign policy of the Republic of Uzbekistan does not legally deny such cooperation. But this is a situation that politically limits the sovereignty and independence of the state, at least in part. We should be primarily interested in building integration in the region with the participation of Central Asian countries. Then we will minimize the threats to the sovereignty and independence of the state.

According to researcher M.M.Omarov [8, 32], Central Asian states should take advantage of the opportunity to unite Central Asia on the basis of regional specificity and mutual regional interests within the framework of the Customs Union under the auspices of Russia. In fact, Central Asian countries, including Uzbekistan, have the opportunity to participate in projects under the "Great Silk Road Economic Route" initiated by the Customs Union or the President of the People's Republic of China Xi Jinping. These two projects are undoubtedly of great importance in the economic development of Central Asian countries. These two projects are undoubtedly of great importance in the economic development of Central Asian countries. The national interests of Uzbekistan and the priorities of economic cooperation require, first of all, economic integration with neighboring countries: Kazakhstan, Turkmenistan, Tajikistan, Kyrgyzstan and Afghanistan (based on the requirements of the
Concept of Foreign Policy of the Republic of Uzbekistan). At the same time, it is extremely important for us to preserve the core of the system, which determines the integration relations, in the Central Asian region. The fact that the core of the integration of Central Asian countries is in Russia or China, undermines the stability of the economy of us and our neighbors. However, this does not mean that Uzbekistan should not participate in the above two projects. Uzbekistan just has to choose the most beneficial path for itself.

One Belt One Road initiative of the People's Republic of China is important in that it prioritizes the long-term economic interests of the countries of the region, including Uzbekistan, within the framework of the Russian-sponsored Customs Union project. The application of the project of the People's Republic of China will be the basis for strengthening economic ties between Europe and Southeast Asia, Uzbekistan's favorable geographical location, large-scale infrastructure and high-tech investments in our economy.

The mechanisms of the Treaty on the Eurasian Economic Union, adopted at the initiative of Russia, are based on a one-sided approach to resolving the fate of deep economic integration [9].

"Our country has always been a crossroads of the Great Silk Road, a crossroads of many trade routes, a place for the exchange of cultures. Ancient Chinese sources mention Tashkent, Samarkand, Bukhara and Khiva as cities that made a great contribution to world civilization. That is why Uzbekistan supported the initiative of the President of the People's Republic of China Xi Jinping to establish the Great Silk Road 
Economic Route. It is an integral part of the One Belt One Road concept. At the international forum in Beijing, President Shavkat Mirziyoyev outlined the country's position on further improving and developing this project. Undoubtedly, our country is interested in the implementation of major projects in the Central Asian region in the field of transport, energy, trade, investment and high technology. Therefore, the region is rich in natural, industrial and human resources. The One Belt One Road initiative provides a platform for participating countries to realize their full potential, complement each other's economies, and encourage trade and investment. "Given the huge financial and economic potential of the Great Silk Road, it is necessary to pay special attention to the implementation of joint projects, primarily aimed at developing infrastructure and creating new industrial capacity."

In addition to the above, we support the initiative of the People's Republic of China to establish the Great Silk Road Economic Line, to gain as much economic benefit from the project as possible, and on its basis to initiate the establishment of the Central Asian Economic Union. It is proposed to develop an international program of organization.

\section{REFERENCES}

1. Болдырев О.Ю. Конституционноправовые проблемы обеспечения экономического суверенитета: Россия, зарубежный опыт: автореферат дис. ... кандидата юридических наук / Моск. гос. ун-т им. М.В. Ломоносова. Москва, 2017. C. 16 .
2. Юсупова М.Н. Формирование трудового потенциала в условиях экономического суверенитета: диссертация ... кандидата экономических наук / Андижанского гос. ун-т им. З.М.Бабура. Ташкент, 1995. - С. 7-9.

3. Юлдошев А. Э. Фуқароларни жамият ва давлат ишларини бошқаришда иштирок этиш хуқуқини таъминлашнинг долзарб масалалари //Журнал правовых исследований. 2020. - T. 5. - №. 11. - Б. 27.

4. Портер М. Международная конкуренция: конкурентное преимущество наций. - М.: Экономика, 1990. Б.128.

5. Tolipov, F. Nationalism as a geopolitical phenomenon: the Central Asian case / F. Tolipov // Centr. Asian survey. Oxford.,2001. - V. 20. - № 2. - P. 194.

6. Интервью Президента Казахстана Н.А. Назарбаева. Рывок в будущее // Central Asia Monitor., 2007. - № 14 (13 апреля).

7. Суюнбаев, М. Центральная Азия в поисках утраченной идентичности / М. Суюнбаев // Центральная Азия и культура мира \ Central Asia a culture of peace. - Бишкек., 2003. - № 1-2. - С. 57.

8. Омаров М.М. Интеграция стран Центральной Азии на основе регеональной идентичности. Вестник Череповецкого государственного университета., 2012. - № 4. Т. 1. - С.32.

9. Договор о Евразийском экономическом союзе (с изменениями на 14 мая 2018 года) (редакция, действующая с 12 марта 2019 года)// 
The American Journal of Political Science Law and Criminology (ISSN - 2693-0803)

Published: July 30, 2021 | Pages: 52-56

Doi: https://doi.org/10.37547/tajpslc/Volume03Issue07-08

(http://docs.cntd.ru/document/420205

962).

10. Boboxonov A. "One Belt One Road": a

great opportunity for mutually beneficial cooperation // This analytical

article was published by a leading researcher of the Institute for Strategic and Interregional Studies under the President of the Republic of Uzbekistan (https://kun.uz/82205768). 